\title{
Histopathological Analysis of Conjunctival Lesions: A 10-Year Experience
}

\section{Konjonktival Lezyonların Histopatolojik Analizi: 10 Yıllık Deneyim}

Siddika Findik ${ }^{1}$,

Nazlı Turk ${ }^{1}$,

Selman Belviranli²,

Pembe Oltulu ${ }^{1}$,

Fahriye Kilinç ${ }^{1}$,

Mehmet Uyar ${ }^{3}$

${ }^{1}$ Department of Pathology, Meram Faculty of Medicine, Necmettin Erbakan University Konya, Turkey.

${ }^{2}$ Department of Ophthalmology, Meram Faculty of Medicine, Necmettin Erbakan University, Konya, Turkey.

${ }^{3}$ Department of Public Health, Meram Faculty of Medicine, Necmettin Erbakan University, Konya, Turkey.

Geliş Tarihi/Received: 2 May 2019

Kabul Tarihi/Accepted: 7 July 2019

Address correspondence to: Siddika Findik, Necmettin Erbakan University Meram Faculty of Medicine, Department of Pathology, Konya, Turkey.

e-mail:drpatolog78@gmail.com

\section{ORCID}

Siddika Findik

https://orcid.org/0000-0002-3364-7498

\section{Öz}

Amaç: Konjonktiva; çeşitli neoplastik yada nonneoplastik lezyonların gelişebileceği bir bölgedir. Bu çalışmada amaç konjonktival lezyonların histopatolojik olarak analizini yapmak ve prevalansını tespit etmektir.

Gereçler ve Yöntem: 2009-2019 yılları arasında patoloji laboratuarına gelen 401 olguya ait konjonktiva biyopsileri retrospektif olarak incelendi. Olgular nonneoplastik ve neoplastik lezyonlar olarak 2 gruba ayrıldı. Neoplastik lezyonlar benign, premalign ve malign lezyonlar olarak alt gruplara bölündü. Lezyonların görülme oranları ile gruplara göre yaş ve cinsiyet dağılımı analiz edildi.

Bulgular: 401 olguya ait serimizde yaş ortalaması $49.89 \pm 21.75$ olup olguların $209(\% 52.1)$ u erkek, $192(\% 47.9)$ i kadın idi. 296 (\%73.8) olguda nonneoplastik,105 (\%26.2) olguda neoplastik lezyon tespit edildi. Nonneoplastik lezyonlarda yas ortalaması $50.79 \pm 19.34$, neoplastik lezyonlarda ise $47.34 \pm 27.39$ idi. Neoplastik lezyonlardan 64'ü (\% 60.2) benign, 17'si (\%16.2) premalign, 24 'ü (\%22.6) malign idi. Pterygium (n:220; \%54.78) en sık görülen nonneoplastik lezyon, nevüsler ve diğer pigmente lezyonlar (n:38; \%9.5) en sık görülen benign lezyon, skuamöz hücreli karsinom (n:14; \%3.5) ise en sık görülen malign lezyon olarak tespit edildi. Neoplastik lezyonların görülme sıklığı 45 yaş üzerinde anlamlı olarak artmakta idi $(p<0.05)$

Sonuç: Pterygium en sık görülen nonneoplastik lezyon olsada özellikle ileri yaşlarda tespit edilen konjonktival lezyonlarda skuamöz hücreli karsinom intimalinin artmış olduğu akılda bulundurulmalıdır.

Anahtar Kelimeler: Konjunktival lezyonlar, non-neoplastik, neoplastik, benign, premalign, malign

\section{Abstract}

Aim: Conjunctiva is a region where various neoplastic or non-neoplastic lesions may develop. In this study, we aimed to perform a histopathological analysis of conjunctival lesions and to determine their prevalence.

Material and Methods: Conjunctival biopsies of 401 patients who presented to the pathology laboratory between 2009 and 2019 were retrospectively examined. The cases were divided into two groups as nonneoplastic and neoplastic lesions. Neoplastic lesions were further divided into subgroups as benign, premalignant, and malignant lesions. The prevalence of lesions and distribution of age and gender among the groups were analyzed.

Results: In our series of 401 patients, the mean age was $49.89 \pm 21.75$ years. Of all patients, $209(52.1 \%)$ were male and $192(47.9 \%)$ were female. Non-neoplastic lesions were found in $296(73.8 \%)$ and neoplastic lesions in 105 (26.2\%) patients. The mean age was found as $50.79 \pm 19.34$ years in patients with nonneoplastic lesions, and $47.34 \pm 27.39$ years in patients with neoplastic lesions. Of neoplastic lesions, 64 $(60.2 \%)$ were benign, $17(16.2 \%)$ premalignant, and $24(22.6 \%)$ malignant. The most commonly found non-neoplastic lesion was pterygium (n:220; $54.78 \%$ ) while the most common benign lesions were nevus and other pigmented lesions $(n: 38 ; 9.5 \%)$, and the most common malignant lesion was squamous cell carcinoma $(n: 14 ; 3.5 \%)$. The prevalence of neoplastic lesions significantly increased over 45 years old $(p<0.05)$.

Conclusion: Pterygium is the most common nonneoplastic lesion, however it should be kept in mind that the possibility of squamous cell carcinoma is increased especially in conjunctival lesions detected in older ages.

Key words: Conjunctival lesions, non-neoplastic, neoplastic, benign, premalign, malign

\section{INTRODUCTION}

Conjunctiva is a thin, transparent membrane covering the inner side of the eyelids, where various lesions may develop (1). Conjunctival lesions show a wide spectrum as benign, premalignant and malignant lesions (2-6). Type and prevalence of tumors may vary depending on age, race, immunity, and chronic exposure (5-7).

Conjunctival tumors are divided into two groups according to their cellular origin as melanocytic and
Cite this article as: Findik $S$, Turk N, Belviranli S, Oltulu P, Kilinc F, Uyar M. Histopathological Analysis of Conjunctival Lesions: A 10-Year Experience. Selcuk Med J 2019;35(3): 159-164
Disclosure: None of the authors has a financial interest in any of the products, devices, or drugs mentioned in this article. The research was not sponsored by an outside organization. All authors have agreed to allow full access to the primary data and to allow the journal to review the allow if requested. 
non-melanocytic tumors (5). Epithelial lesions take place in a wide spectrum from benign lesions such as papilloma to malignant lesions like squamous cell carcinoma (SCC). The most important three malign tumors include ocular surface squamous neoplasia (OSSN), melanoma, and lymphoma (8).

OSSN include dysplasia, carcinoma in situ and SCC lesions (4). Several factors such as chronic solar radiation, HIV, HPV, HBV, HCV, organ transplantation, autoimmune diseases, xeroderma pigmentosum and smoking are accused as the predisposing factors in OSSN $(7,9-13)$. The predisposing factors in melanoma have been reported as primary acquired melanosis (PAM), chronic nevi, and chronic solar radiation (14). Where as benign reactive lymphoid hyperplasia, HIV, immune dysfunction, autoimmune diseases, genetic mutations, and chronic inflammation (helicobacter pylori, Chlamydia psittaci) play a role in conjunctival lymphomas $(7,15,16)$.

Recognition of conjunctival tumors and understanding the predisposing factors are crucial. In this study we aimed to perform a histopathological analysis of conjunctival lesions and to determine their prevalence.

\section{MATERIAL AND METHODS}

The study was approved by the board of our university and conducted according to the ethical principles of the Declaration of Helsinki. Conjunctival biopsies of 401 patients who presented to the pathology laboratory of the Necmettin Erbakan University Meram Medical Faculty between 2009 and 2019 were retrospectively examined. The cases were divided into two groups as non-neoplastic and neoplastic. Non-neoplastic lesions were further divided into four groups as degenerative lesions, conjunctival cysts, inflammatory lesions, and subconjunctival fat prolapse; while neoplastic lesions were divided into three groups as benign, premalignant, and malignant. The patients were additionally divided into four age groups as 0-18, 19-44, 45-64, and >65 years old. Cases were evaluated histopathologically and the frequency of conjunctival lesions and the distribution rates according to age were determined.

The data were analyzed using SPSS version 24.0 statistical software. Continuous counted variables for descriptive statistics are expressed as mean \pm standard deviation and percentages. Chi-square was used in the comparison of categorical variables. $\mathrm{P}<0.05$ values were considered statistically significant.

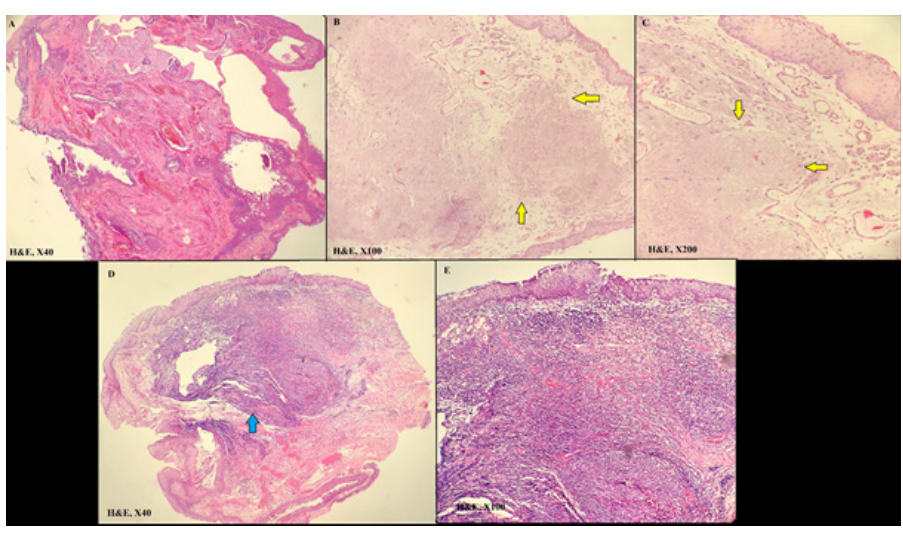

Figure 1. Non-neoplastic lesions; A-H\&E x40, B- H\&E x100, C-H\&E x200 Pterygium. Subepitelial basophilic fibrillar degeneration (yellow arrows), vascular congestion. D-H\&E $\mathrm{x} 40$ and $\mathrm{E}-\mathrm{H} \& \mathrm{E} \times 100$ Conjunctivitis. Subepitelial inflamation (blue arrow).

\section{RESULTS}

In our series, the patients were aged between 1-96 years with a mean age of $49.89 \pm 21.75$ years. Of all patients, 209 (52.1\%) were male and 192 (47.9\%) were female. Non-neoplastic lesions were found in 296 (73.8\%) and neoplastic lesions in 105 (26.2\%) patients. The mean age was found as $50.79 \pm 19.34$ years in patients with non-neoplastic lesions, and $47.34 \pm 27.39$ years in patients with neoplastic lesions. Of the 296 non-neoplastic lesions; 220 were pterygium (74.3\%), $35(11.8 \%)$ non-specific inflammation (conjunctivitis), and $25(8.4 \%)$ conjunctival inclusion cysts, in order of frequency (Figure-1). Non-neoplastic lesions were

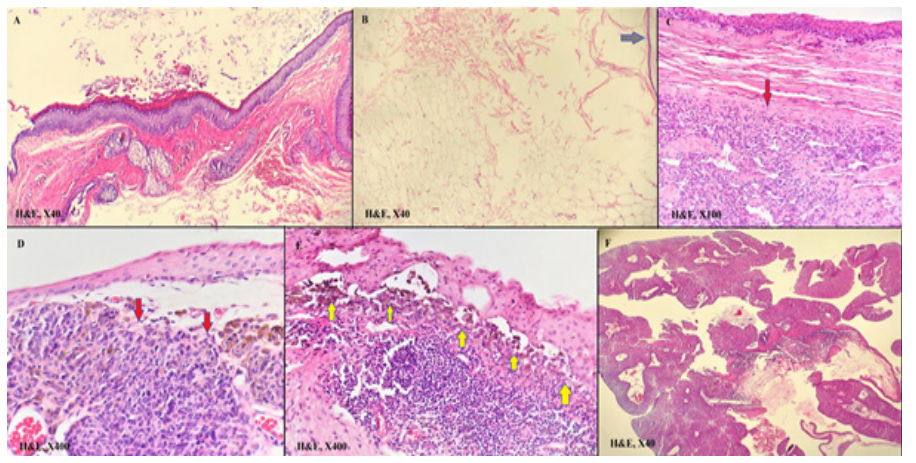

Figure 2. Non-neoplastic and benign neoplastic lesions; A-H\&E x40 Dermoid cyst. B-H\&E x40 Subconjunctival Fat Prolapse (blue arrow: atrophic squamous epithelium). C-H\&E x100 Hemangioma. D and E- H\&E x400 Subepitelial and junctional nevus. F- H\&E x40 Squamous papilloma). 


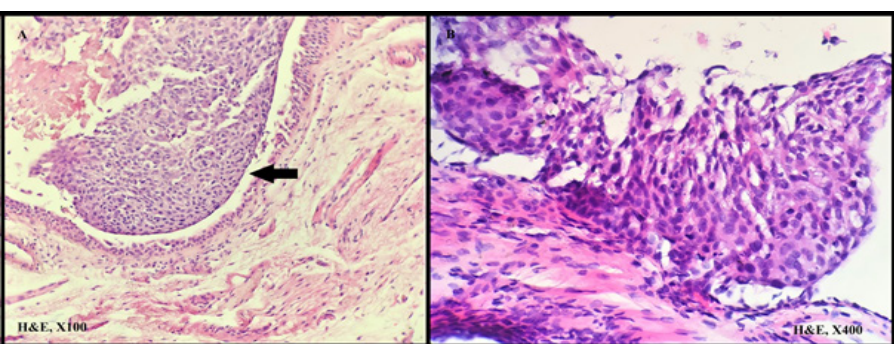

Figure 3. Premalignant lesions; $A-H \& E \times 100$ and $B-H \& E$ x400 Conjunctival intraepitelial neoplasia-III (carcinoma in situ).

found in 152 (51.4\%) male and 144 (48.6) female patients. Of the 105 neoplastic lesions; 64 (60.2\%) were benign (Figure-2), 17 (16.2\%) premalignant (Figure-3), and $24(22.6 \%)$ malignant (Figure-4). Of the neoplastic lesions; 38 (36.2\%) were nevi and other benign pigmented lesions, $16(15.2 \%)$ conjunctival intraepithelial neoplasia, and $14(13.3 \%)$ squamous cell carcinoma (SCC) (Table-1). The histopathologic imaging was compatible with combined nevus in 23 $(63.8 \%)$, subepithelial nevus in $11(30.5 \%)$, junctional nevus in one $(2.8 \%)$, and blue nevus in one $(2.8 \%)$ of the 36 cases with nevus detected. Neoplastic lesions were found in 57 (54.3\%) male and 48 (45.7\%) female patients. Benign neoplasms were found in $35(56.5 \%)$ male and $27(43.5 \%)$ female patients,

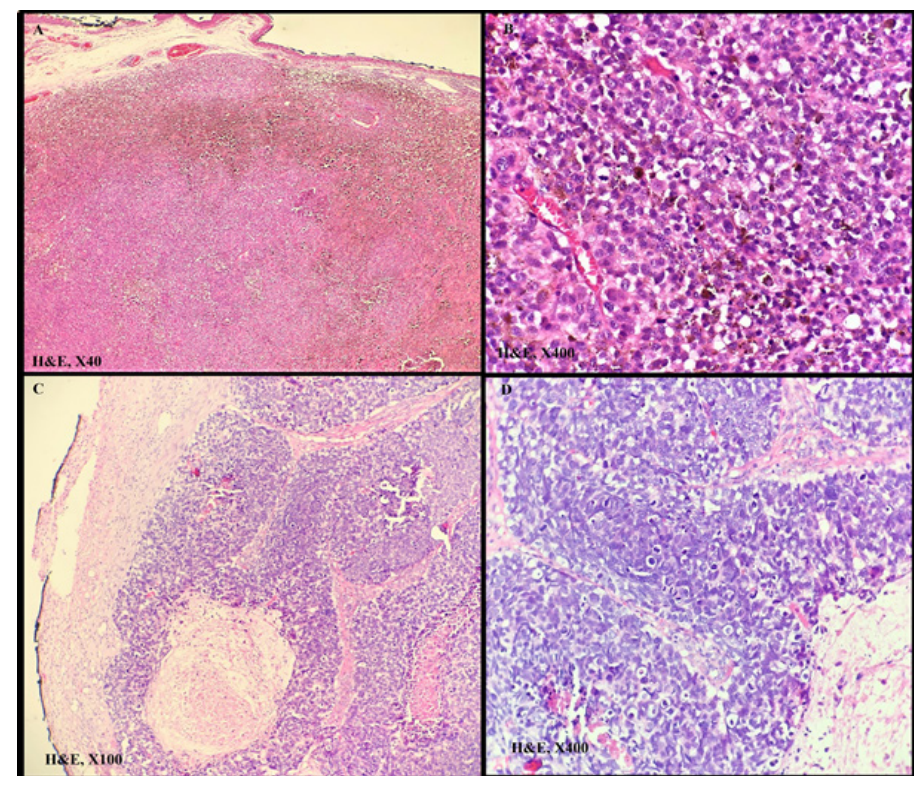

Figure 4. Malignant lesions; A-H\&E $x 40$ and $B-H \& E$ x400 Malignant melanoma. C-H\&E x100 and D-H\&E x400 Squamous Cell Carcinoma. while premalignant lesions were found in 12 (66.7\%) male and $6833.3 \%$ ) patients, and malignant lesions were found in 10 (40.0\%) male and 15 (60.0\%) female patients. No statistically significant difference was found between the groups in terms of gender. The prevalence of neoplastic lesions significantly increased over 45 years of age $(p<0.05)$.

\section{DISCUSSION}

Conjunctia is a mucous membrane found inside the eyelids, expending to the limbus. It consists of the epithelial layer (Columnar epithelium, mucin secreting goblet cells and melanocytes) and supportive stromal tissue. The epithelium and secretion of the conjunctiva are the most important defence mechanism of the bulbus against foreign bodies. Neoplastic lesions of the conjunctiva generally have similar properties with the dermal and mucosal lesions in the other regions of the organism. Some tumoral lesions that may cause difficulty in the diagnosis due to specific structural components may arise in this region. Diagnostic difficulties may be encountered because of small biopsy samples taken from this region in lesions that may have different histomorphological appearance and clinical behaviours. A correct histopathological diagnosis is an important factor guiding the protection of visual functions and cosmetically important operations (17-20).

In a study conducted in 2017 with 5002 cases, $52 \%$ of conjunctival tumors were reported as benign, $18 \%$ as premalignant, and $30 \%$ as malignant. In the same study, the most common tumoral lesions seen in all age groups were respectively found as nevi (23\%), OSSN (14\%), PAM (12\%), melanoma $(12 \%)$, and lymphoma (7\%). In that series, Kaposi's sarcoma, metastatic tumors, plasmacytomas and leukemias were found as under 1\% (21). In another study, the most common type of lesions was found as benign (81.8\%) followed by premalignant $(10.8 \%)$ and malignant $(7.4 \%)$ lesions in all age groups. In the same study, the most common benign lesion was found as pterygium (56.6\%) (22). In a study from Turkey with limited number of patients, $95 \%$ of conjunctival lesions were reported as benign, and $5 \%$ as malignant lesions. In that study, the most commonly observed benign lesions were melanocytic nevi $(57.9 \%)$, hemangiomas $(26.3 \%)$, and cystic lesions $(15.8 \%)$, respectively. Whereas the most commonly seen malignant neoplasia was reported as SCC by $5 \%(1)$.

In our study, $73.8 \%$ of conjunctival lesions were 
Table 1. Classification and Frequency of Nonneoplastic and Neoplastic Conjunctival Lesions

\begin{tabular}{|c|c|c|c|}
\hline & Total Frequency $\mathrm{n}(\%)$ & Percentage in groups & Mean age \\
\hline Nonneoplastic lesions & $296(73.8)$ & & $50.79 \pm 19.34$ \\
\hline Degenerative Lesions & $222(55.27)$ & & $55.27 \pm 15.38$ \\
\hline Pterygium & $220(54.78)$ & 99.1 & \\
\hline Pinguekula & $2(0.49)$ & 0.9 & \\
\hline Inflammatory Lesions & $40(9.96)$ & & $37.22 \pm 25.20$ \\
\hline Nonspecific Inflammation & $35(8.72)$ & 87.5 & \\
\hline $\begin{array}{l}\text { Benign reactive } \\
\text { lymphoid hyperplasia }\end{array}$ & $5(1,24)$ & 12.5 & \\
\hline Cysts & $28(6,96)$ & & $35.64 \pm 21.61$ \\
\hline Conjunctival inclusion cyst & $25(6.22)$ & 89.2 & \\
\hline Dermoid cyst & $3(0.74)$ & 10.8 & \\
\hline Subconjunctival Fat Prolapse & $6(1.49)$ & & $46.16 \pm 21.64$ \\
\hline Neoplastic Lesions & $105(26.2)$ & & $47.34 \pm 27.39$ \\
\hline Benign & $64(16)$ & & $32.87 \pm 22.90$ \\
\hline $\begin{array}{l}\text { Papilloma and } \\
\text { verrucous lesions }\end{array}$ & $16(4.0)$ & 25 & \\
\hline $\begin{array}{l}\text { Nevus and other } \\
\text { benign pigmented lesions }\end{array}$ & $38(9.5)$ & 59.5 & \\
\hline Hemangioma & $8(2.0)$ & 12.5 & \\
\hline Dermolipoma & $1(0.24)$ & 1.5 & \\
\hline Schwannoma & $1(0.24)$ & 1.5 & \\
\hline Premalignant & $17(4.24)$ & & $60.11 \pm 22.67$ \\
\hline $\operatorname{CIN}(I-I I-I I I)^{*}$ & $16(4.0)$ & 94.1 & \\
\hline PAM $1^{* *}$ & $1(0.24)$ & 5.9 & \\
\hline Malignant & $24(6.0)$ & & $74.04 \pm 12.18$ \\
\hline $\mathrm{SCC}^{* * *}$ & $14(3.5)$ & 58.3 & \\
\hline Secondary Invasion & $6(1.5)$ & 25 & \\
\hline Malignant melanoma & $2(0.5)$ & 8.4 & \\
\hline Plasma cell neoplasm & $1(0.24)$ & 4.1 & \\
\hline Lymphoma & $1(0.24)$ & 4.1 & \\
\hline Total & 401 & & \\
\hline
\end{tabular}

${ }^{*} \mathrm{CIN}$, Conjunctival intraepitelial neoplasia, ${ }^{\text {**} P A M}$, Primary Acquired Melanosis

***SCC Squamous Cell Carcinoma

non-neoplastic, and $26.2 \%$ were neoplastic lesions. Consistently with the literature, the most common non-neoplastic lesion was pterygium $(74.3 \%$ of nonneoplastic lesions) and the most common benign neoplastic lesion was nevus $(59.4 \%$ of benign neoplastic lesions). In our series, CIN was found to be the most commonly seen lesion. Evaluating all lesions, the rate of conjunctival malignancy in our series was $6 \%$. SCC which constituted $58.3 \%$ of malignant neoplasia, was the most common malignant neoplasia followed by secondary invasions $(25.0 \%)$, malignant melanoma (8.3\%), plasmacytoma (4.1\%), and lymphoma (4.1\%). Clinical studies have reported prevalences of pterygium and pinguecula that are among the degenerative lesions, in a wide range. The region of study may affect this difference. While the prevalence of pterygium has been reported between $1 \%$ and $33 \%$, the prevalence may vary from $20 \%$ to $70 \%$ for pinguecula (23). However, since the need for surgical excision is less for pinguecula, pterygium is more commonly encountered in pathologic series.

Although not seen in a significant portion, subconjunctival fat prolapse is a non-neoplastic condition that should be taken into account, because it can be misdiagnosed as lipoma in the absence of clinical information. Actually, subconjunctival fat prolapse is not a pathology belonging to the conjunctiva. There is no any pathology in the overlying conjunctiva. However, these specimens are included in the pathological classification since they are recorded as conjunctival mass excision. Mean age in conjunctival OSSN has been reported as 56 years in the literature. It is seen in younger ages as approaching to the equator (9). In our study, it was found that carcinoma in situ occured 5 to 9 years earlier than invasive carcinoma. In the current study, an increase was observed in neoplastic lesions in patients aged over 45 years, while the mean age was found as $60.11 \pm 22.67$ in premalignant and $74.04 \pm 12.18$ in malignant lesions. Consistently 
with the literature, premalignant lesions manifest about 10 year earlier than invasive lesions, and this provides information on the progression of tumors. Premalignant and malignant lesions were seen in earlier ages compared to the literature and this may be related to relatively more limited actinic injury due to the seasonal conditions in our region.

Some previous studies have reported that conjunctival lesions are more common in men $(8,9)$, while some studies have reported no difference in gender (22). In the present study, conjunctival lesions were more common in the male patients at $52.1 \%$. In addition, no significant difference was found between the groups in terms of the incidence of lesions and gender. This result is consistent with the data from the literature, but it should be noted that the number of patients in the subgroups was limited. Limitations of this study are limited number of patients and its single center design.

In the literature, conjunctival lesions are usually grouped as benign, premalignant, and malignant lesions or conjunctival tumors. Whereas in our study, a different classification was developed as nonneoplastic and neoplastic lesions, and particularly non-neoplastic lesions were discussed in detail in order to shed light for the literature.

\section{CONCLUSION}

In this study, basic histopathological analysis of conjunctival lesions was performed with a 10-year case accumulation. The assessment of conjunctival lesions requires a careful clinical evaluation and a correct histopathologic approach. Besides understanding conjunctival lesion classification, considering that despite the sum of nonneoplastic and benign lesions are 8-9 folds more common than premalignant and malignant lesions, premalignant and malignant lesions may be encountered by about $10 \%$; require more careful clinical and histopathological evaluation of conjunctival lesions. Increment of experience in clinical and histopathological diagnosis of the lesions in this region will contribute to correct guiding of the treatment.

Although pterygium is the most common nonneoplastic lesion, it should be kept in mind that the possibility of squamous cell carcinoma is increased especially in conjunctival lesions detected in older ages.

Conflict of interest: Authors declare that there is no conflict of interest between the authors of the article.
Financial conflict of interest: Authors declare that they did not receive any financial support in this study.

Address correspondence to: Sidika Findik, Necmettin Erbakan University Meram Faculty of Medicine, Department of Pathology, Akyokus Mevkii, Konya, Turkey, postal code: 42090 .

e-mail: drpatolog78@gmail.com

\section{REFERENCES}

1. Kandemir NO, Barut F, Bektaş S, et al.Tumors and tumor like lesions of the eyelid and conjonctiva. Turkish $\mathrm{J}$ Patho 2009;25(3):112-7.

2. Shields JA, Shields CL. Eyelid, conjunctival, and orbital tumors. In: An atlas and textbook. Philadelphia: Lippincott Wolters Kluwers, 2016;251-44.

3. Shields CL, Shields JA. Tumors of the conjunctiva and cornea. Surv Ophthalmol 2004;49:3-24.

4. Grossniklaus HE, Green WR, Luckenbach $M$, et al. Conjunctival lesions in adults. A clinical and histopathologic review. Cornea 1987;6:78-116.

5. Shields CL, Demirci H, Karatza E, et al. Clinical survey of 1643 melanocytic and nonmelanocytic tumors of the conjunctiva. Ophthalmology 2004;111:1747-54.

6. Shields CL, Alset AE, Boal NS, et al. Conjunctival tumors in 5002 cases. Comparative analysis of benign versus malignant counterparts. The 2016 James D. AllenLecture. Am J Ophthalmol 2017;173:106-33.

7. Verma V, Shen D, Sieving PC, et al. The role of infectious agents in the etiology of ocular adnexal neoplasia. Surv Ophthalmol 2008;53:312-31.

8. Alves LF, Fernandes BF, Burnier JV, et al. Incidence of epithelial lesions of the conjunctiva in a review of 12.102 specimens in Canada (Quebec). Arq Bras Oftalmol 2011;74:21-3.

9. Lee GA, Hirst LW. Ocular surface squamous neoplasia. Surv Ophthalmol 1995;39:429-50.

10. Basti S, Macsai MS. Ocular surface squamous neoplasia: A review. Cornea 2003;22:687-704.

11. Ramberg I, Heegaard S, Prause JU, et al. Squamous cell dysplasia and carcinoma of the conjunctiva. A nation wide, retrospective, epidemiological study of Danish patients. Acta Ophthalmol 2015;93:663-6.

12. Shields CL, Ramasubramanian A, Mellen $P$, et al. Conjunctival squamous cell carcinoma arising in immunosuppressed patients (organ transplant, human immunodeficiency virus infection). Ophthalmology 2011;118:2133-7.

13. Lloyd HCM, Arunga S, Twinamasiko A, et al. Predictors of ocular surface squamous neoplasia and conjunctival squamous cell carcinoma among Ugandan patients: A hospital-based study. Middle East Afr J Ophthalmol 2018; 25(3-4): 150-5.

14. Shields CL, Markowitz JS, Belinsky I, et al. Conjunctival melanoma. Outcomes based on tumor origin in 382 consecutive cases. Ophthalmology 2011;118:389-95.

15. Foster LH, Portell CA. The role of infectious agents, antibiotics, and antiviral therapy in the treatment of extranodal marginal zone lymphoma and other low-grade lymphomas. Curr Treat Options Oncol 2015;16:28.

16. Sjö NC, Foegh $P$, Juhl BR, et al. Role of Helicobacter pylori in conjunctival mucosa-associated lymphoid tissue lymphoma. 
Ophthalmology 2007;114:182-6.

17. Lasudry J. Palpebral tumors: Clinical and diagnostic considerations. J Fr Ophtalmol 2003;26:70-6.

18. Chi MJ, Baek SH. Clinical analysis of benign eyelid and conjunctival tumors. Ophtalmologica 2006;220:43-51.

19. Scat Y, Liotet S, Carre F. Epidemiological study of benign tumors and inflammatory pseudotumors of the eye and its adnexa. J Fr Ophtalmol 1996;19:514-9.

20. Holbach LM, Pogorelov P, Kruse FE. Differential diagnosis and treatment options for conjunctival tumors. Ophthalmologe 2007;104(6):521-38.
21. Shields CL, Chien JL, Surakiatchanukul T, et al. Conjunctival tumors: Review of clinical features, risks, biomarkers, and outcomes-The 2017 J. Donald M. Gass Lecture. Asia-Pac J Ophthalmol 2017;6(2):109-20.

22. Aliakbar-Navahi R, Ashraf MJ, Seirfar N. Conjunctival Lesions; A histopathologic review in Fars province. Iran J Ophthalmic Vis Res 2015;10(2): 98-101.

23. Fotouhi $A$, Hashemi $H$, Khabazkhoob $M$, et al.Prevalence and risk factors of pterygium and pinguecula: The Tehran eye study. Eye (Lond) 2009;23(5):1125-9. 